\title{
Shortening of alkaline DNA unwinding time does not interfere with detecting DNA damage to mouse and human spermatozoa in the comet assay
}

\author{
Hirokazu Kusakabe and Hiroyuki Tateno
}

The comet assay was performed on mouse and human spermatozoa to examine the effect of alkaline DNA unwinding time. The spermatozoa were treated in vitro with the DNA-damaging agents, methyl methanesulfonate $(\mathrm{MMS})$ or hydrogen peroxide $\left(\mathrm{H}_{2} \mathrm{O}_{2}\right)$, and then embedded in agarose gel on glass slides. The slides were immersed in alkaline solution ( $>$ pH 13) for 1, 5, 10 and 20 min, and then subjected to the electrophoresis under neutral conditions. In mouse spermatozoa, comet tails seen in solvent controls became brighter and longer as the alkaline DNA unwinding time increased. However, in the MMS-treated mouse spermatozoa, a smaller difference in the damage from that in the solvent control was seen with time within a dose. DNA damage induced by $\mathrm{H}_{2} \mathrm{O}_{2} \mathrm{could}_{\text {also be detected }}$ accurately after alkali treatment for 1-20 min. In human spermatozoa, DNA damage induced by $\mathrm{MMS}$ and $\mathrm{H}_{2} \mathrm{O}_{2}$ could be detected in a dose-dependent manner after alkali treatment for $1 \mathrm{~min}$. The ability of the comet assay to detect DNA damage was not adversely affected by the short period ( $1 \mathrm{~min}$ ) of the alkaline DNA unwinding time.

Asian Journal of Andrology (2011) 13, 172-174; doi:10.1038/aja.2010.105; published online 8 November 2010

Keywords: alkaline; comet assay; DNA unwinding; human; mice; spermatozoa

\section{INTRODUCTION}

Single-cell gel electrophoresis assay (the comet assay) is a simple and high-throughput technique to detect the cellular DNA damage induced by various types of genotoxicants in situ. The comet assay is performed in one of two versions, alkaline and neutral. Alkaline comet assays visualize single- and double-strand breaks in cellular DNA, whereas the neutral comet assay reveals mainly double-strand breaks. Nowadays, the alkaline comet assay of reproductive cells has been recommended to screen genotoxic hazards. Furthermore, it is more practical in larger studies to evaluate the DNA integrity of cryopreserved mammalian spermatozoa. ${ }^{1}$

The standard alkaline comet assay includes a step of alkali treatment to unwind the DNA before electrophoresis under the alkaline condition. In another version of the assay, cells embedded in agarose gel are treated with an alkali ( $>$ pH 13) followed by electrophoresis under neutral conditions. This protocol is named the ' $\mathrm{A} / \mathrm{N}$ protocol'. ${ }^{2}$ Lower background levels of DNA damage and better dose responses are obtained by the A/N protocol. ${ }^{2-4}$

Recently, the comet assay A/N protocol has been reported for murine spermatozoa. ${ }^{5-7}$ In most cases, the alkaline DNA unwinding time is set at $20 \mathrm{~min}$ or more. To our knowledge, there is little information on the optimal time of alkali treatment to detect sperm DNA damage with the $\mathrm{A} / \mathrm{N}$ protocol. In the present study, the optimal time of the alkali treatment was determined for mouse spermatozoa by the comet assay with A/N protocol.

\section{MATERIALS AND METHODS}

Animals

Hybrid (B6D2F 1 ) male mice (7-12 weeks of age) were used in this study. The animals were maintained under a 14-h light/10-h dark photoperiod at a temperature of $22-24{ }^{\circ} \mathrm{C}$. All experiments were performed according to the Guidelines for Animal Experiments of Asahikawa Medical University (Asahikawa, Japan).

\section{Collection and treatment of mouse spermatozoa}

Dense masses of mature spermatozoa were collected from the cauda epididymidis and placed at the bottom of a $1.5-\mathrm{ml}$ polypropylene microcentrifuge tube containing $1.2 \mathrm{ml}$ of ToyodaYokoyama-Hosi medium. ${ }^{8}$ The tube was left standing for $10 \mathrm{~min}$ at $37{ }^{\circ} \mathrm{C}$ to allow the spermatozoa to disperse by swimming into the medium. The spermatozoa were treated with $12.5-100 \mu \mathrm{g} \mathrm{ml}^{-1}$ methyl methanesulfonate (MMS) or 25-100 $\mu \mathrm{mol} 1^{-1}$ hydrogen peroxide $\left(\mathrm{H}_{2} \mathrm{O}_{2}\right.$; Nacalai Tesque, Kyoto, Japan) for $2 \mathrm{~h}$ at $37{ }^{\circ} \mathrm{C}$ under $5 \% \mathrm{CO}_{2}$ in air. MMS or $\mathrm{H}_{2} \mathrm{O}_{2}$ were dissolved in distilled water and added to the sperm suspension at $1 \%$ of the volume of the suspension.

Collection and treatment of human spermatozoa

Semen samples provided by a healthy volunteer were allowed to liquefy at $37^{\circ} \mathrm{C}$ for $30 \mathrm{~min}$. A $0.5 \mathrm{ml}$ aliquot was gently placed at the bottom of a small test tube containing $2 \mathrm{ml}$ of Tris-buffered ethylene 
glycol-bis ( $\beta$-aminoethyl ether)- $N, N, N^{\prime}, N^{\prime}$-tetraacetic acid solution ${ }^{9}$ that had been prewarmed to $37{ }^{\circ} \mathrm{C}$. The tube was left standing for $10 \mathrm{~min}$ at $37^{\circ} \mathrm{C}$ to allow spermatozoa to disperse into the solution. In all, $1 \mathrm{ml}$ of the upper layer containing the spermatozoa was transferred into another test tube. The spermatozoa were treated with 50-200 $\mu \mathrm{g} \mathrm{ml}^{-1}$ MMS or 0.01-1 mmol $\mathrm{l}^{-1} \mathrm{H}_{2} \mathrm{O}_{2}$ for $2 \mathrm{~h}$ at $37^{\circ} \mathrm{C}$ under $5 \% \mathrm{CO}_{2}$ in air. MMS or $\mathrm{H}_{2} \mathrm{O}_{2}$ were dissolved in distilled water and added to the sperm suspension at $1 \%$ of the volume of the suspension.

\section{Comet assay}

Normal melting agarose (NMA; Agarose L03; Takara Bio, Otsu, Japan) was dissolved in phosphate-buffered saline without $\mathrm{Ca}^{2+}$ and $\mathrm{Mg}^{2+}, \mathrm{pH} 6.8$ at the concentration of $1.0 \%(\mathrm{w} / \mathrm{v})$ and kept at $50{ }^{\circ} \mathrm{C}$. The surface on each glass slide was smeared with the 1\% NMA on a plate heated at $70{ }^{\circ} \mathrm{C}$. The sperm suspension was mixed with the $1 \%$ NMA to the final concentration of $0.7 \%$ NMA and the mixture $(100 \mu \mathrm{l})$ was applied on each presmeared glass slide warmed at $50{ }^{\circ} \mathrm{C}$, and coverslips were placed on the slides and then stored at $4{ }^{\circ} \mathrm{C}$ for $10 \mathrm{~min}$.

After removing the coverslips, the slides were incubated at $4{ }^{\circ} \mathrm{C}$ for $2 \mathrm{~h}$, and then further for $1 \mathrm{~h}$ at $37^{\circ} \mathrm{C}$ in lysis buffer composed of $2.5 \mathrm{~mol} \mathrm{l}^{-1} \mathrm{NaCl}, 50 \mathrm{mmol} \mathrm{l}^{-1}$ EDTA-Na, $10 \mathrm{mmol} \mathrm{l}^{-1}$ Tris- $\mathrm{HCl}$ $(\mathrm{pH} 10), 1 \%(\mathrm{v} / \mathrm{v})$ Triton X-100 and $10 \mathrm{mmol} \mathrm{l}^{-1}$ DL-dithiothreitol (Sigma-Aldrich, Buchs, Switzerland).

The slides were washed three times ( 3 min each) with cold water $\left(4{ }^{\circ} \mathrm{C}\right)$. Subsequently, the slides were immersed for exactly $1,5,10$ and $20 \mathrm{~min}$ in $300 \mathrm{mmol}^{-1} \mathrm{NaOH}$ supplemented with $1 \mathrm{mmol} \mathrm{l}^{-1}$ EDTA-Na $\left(4^{\circ} \mathrm{C}\right)$, and then transferred to Tris-acetate-EDTA buffer, $\mathrm{pH} 8.3$ (Sigma-Aldrich, St Louis, MO, USA) for neutralization. The slides were subjected to electrophoresis for $10 \mathrm{~min}(12 \mathrm{~V}, 10 \mathrm{~mA})$ at room temperature in Tris-acetate-EDTA buffer. After electrophoresis, the slides were immersed in ethanol $(100 \%)$ and air dried. Immediately or 1 day afterwards, the air-dried slides were stained by YOYO iodide (Invitrogen, Eugene, OR, USA).

In each assay, 50 comets per slide were analyzed using a fluorescent microscope (Olumpus, Tokyo, Japan). The percentage of DNA in the comet tail (\% tail DNA) was measured with the software CometScore Freeware version 1.5 (TriTek, Sumerduck, VA, USA).

\section{Statistical analysis}

The mean \% tail DNAs were compared using analysis of variance followed by Fisher's least significant difference for multiple comparisons. Significant differences were determined at $P<0.05$.

\section{RESULTS AND DISCUSSION}

At each instance of alkali treatment, MMS-induced DNA damage clearly showed a dose-dependent increase (Figure 1). Alkali treatment contributed to the higher \% tail DNA in the solvent control. With regard to MMS-treated spermatozoa, the \% tail DNA did not increase significantly with the time of alkali treatment (from 1 to 5 or $10 \mathrm{~min}$, Figure 1). Comet tails appeared brighter at $20 \mathrm{~min}$ than at $1 \mathrm{~min}$ (Figure 2). The comet tails were fairly pale in alkali treatment for $1 \mathrm{~min}$ in the solvent control, representing a low background level of DNA damage (Figure 2a). Mouse spermatozoa were treated with MMS at doses of 12.5 and $25.0 \mu \mathrm{g} \mathrm{ml}$ (Figure 3). Alkali treatment for $1 \mathrm{~min}$ induced considerable lower background DNA damage, resulting in a statistically significant difference $(P<0.05)$ of damage between solvent control and the lowest dose of MMS $\left(12.5 \mu \mathrm{g} \mathrm{ml}^{-1}\right)$. In contrast, no significant difference

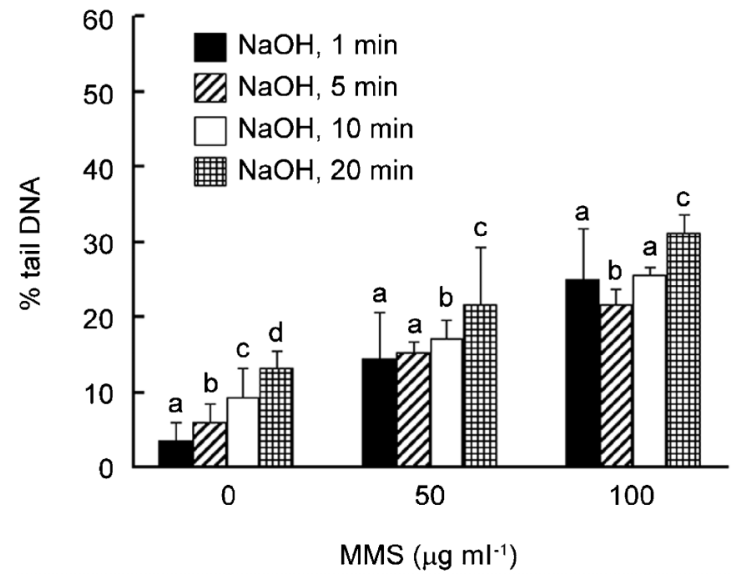

Figure 1 Results of comet assay using mouse spermatozoa treated in vitro with 50 and $100 \mu \mathrm{g} \mathrm{m}^{-1} \mathrm{MMS}$. At each dose of MMS, three independent experiments were performed with one mouse per experiment. Treatment with $\mathrm{NaOH}$ was carried out to unwind the spermatozoal DNA for 1, 5, 10 and 20 min before electrophoresis. Data are expressed as mean \pm SD. Bars not sharing the common letters $(a-d)$ differ significantly $(P<0.05)$ within a dose of MMS. MMS, methyl methanesulfonate.
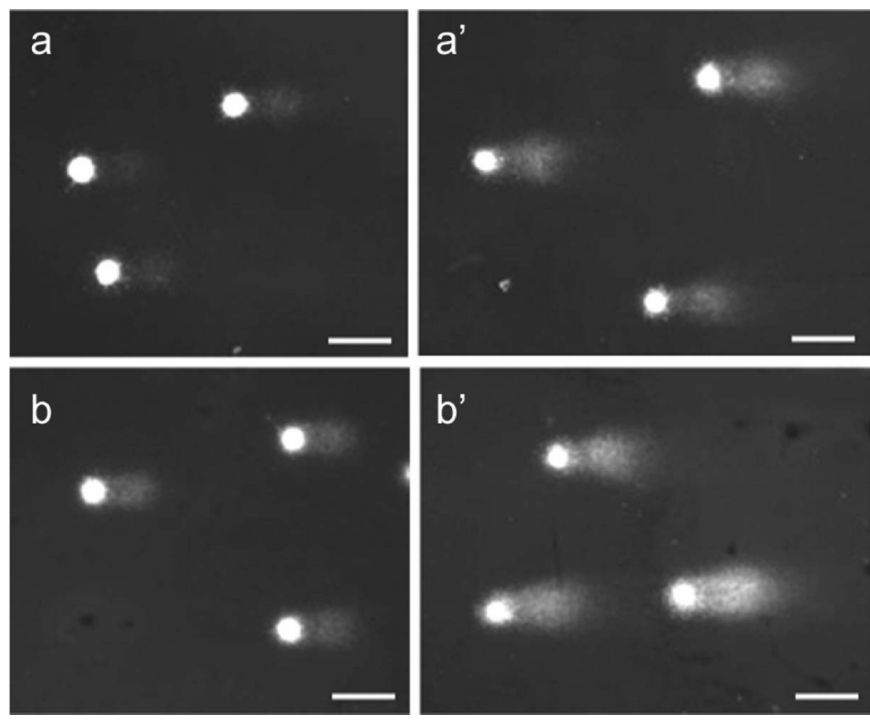

Figure 2 Comets of mouse spermatozoa assayed according to the A/N protocol Alkaline DNA unwinding time was set at $1 \mathrm{~min}$ (a, solvent control; $\mathbf{a}^{\prime}, 100 \mu \mathrm{g} \mathrm{ml} \mathrm{I}^{-1}$ MMS) and $20 \mathrm{~min}$ (b, solvent control; b' $100 \mu \mathrm{g} \mathrm{ml} \mathrm{m}^{-1} \mathrm{MMS}$ ). Scale bars $=50 \mu \mathrm{m}$. MMS, methyl methanesulfonate.

in the damage was seen at this dose when alkali treatment was carried out for $20 \mathrm{~min}$ (Figure 3).

In the standard alkaline comet assay on mouse skin keratinocytes, long-term treatment ( $8 \mathrm{~h}$ or more) with alkali caused an increase in the background damage in the control cells. ${ }^{10}$ DNA damage induced by genotoxins may be concealed by overlap with the background damage level.

DNA damage induced in mouse spermatozoa by $\mathrm{H}_{2} \mathrm{O}_{2}$ could be detected at the doses of $50 \mu \mathrm{mol} \mathrm{l}^{-1}$ or more (Figure 4). Under this assay condition, both background DNA damage and $\mathrm{H}_{2} \mathrm{O}_{2}$-induced DNA damage showed a little difference among alkaline DNA unwinding times. It was found that shortening the alkaline DNA unwinding time did not interfere with the detection of DNA damage induced in mouse spermatozoa by $\mathrm{H}_{2} \mathrm{O}_{2}$. 


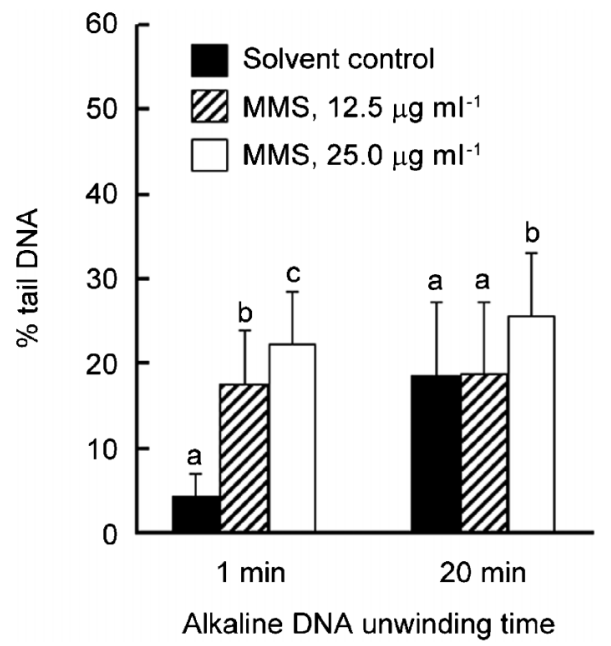

Figure 3 Results of comet assay using mouse spermatozoa treated in vitro with 12.5 and $25.0 \mu \mathrm{g} \mathrm{ml}^{-1} \mathrm{MMS}$. At each dose of MMS, four independent experiments were performed with one mouse in each experiment. Treatment with $\mathrm{NaOH}$ was carried out to unwind the spermatozoal DNA for 1 and 20 min before electrophoresis. Data are expressed as mean \pm SD. Bars not sharing the common letters $(a-c)$ differ significantly $(P<0.05)$ within the alkaline DNA unwinding time. MMS, methyl methanesulfonate.

a

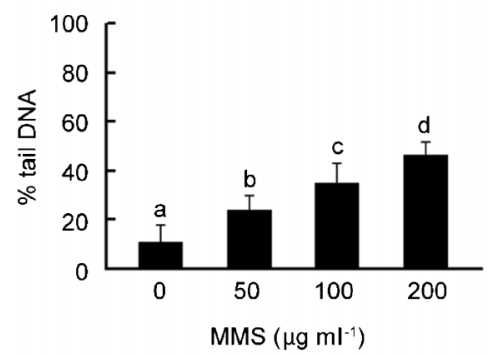

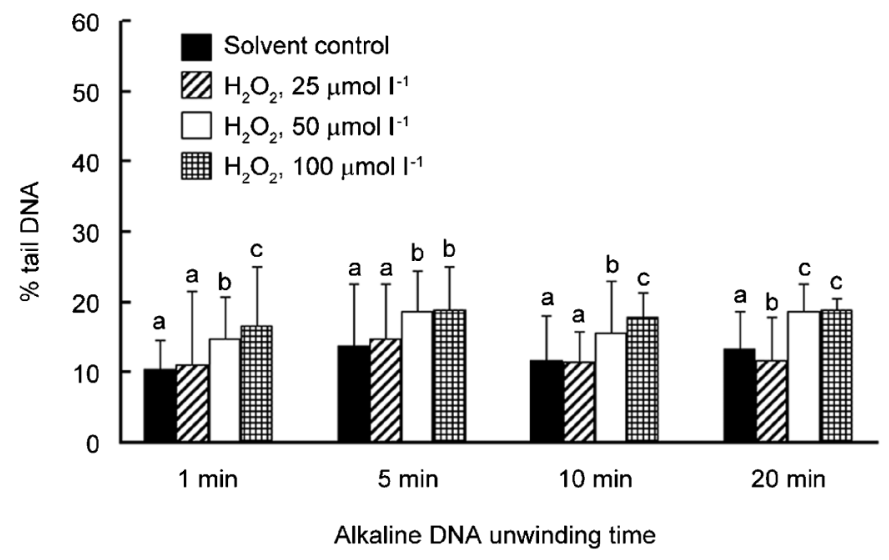

Figure 4 Results of Comet assay using mouse spermatozoa treated in vitro with 25-100 $\mu \mathrm{mol} \mathrm{I}^{-1} \mathrm{H}_{2} \mathrm{O}_{2}$. At each dose of $\mathrm{H}_{2} \mathrm{O}_{2}$, three independent experiments were performed with one mouse in each experiment. Treatment with $\mathrm{NaOH}$ was carried out to unwind the spermatozoal DNA for 1, 5, 10 and 20 min before electrophoresis. Data are expressed as mean \pm SD. Bars not sharing the common letters $(a-c)$ differ significantly $(P<0.05)$ within the alkaline DNA unwinding time. $\mathrm{H}_{2} \mathrm{O}_{2}$, hydrogen peroxide.

b

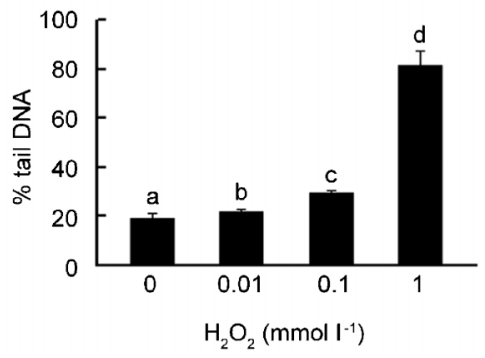

Figure 5 Results of comet assay using human spermatozoa treated in vitro with (a) 50-200 $\mu$ g ml ${ }^{-1}$ MMS and (b) $0.01-1 \mathrm{mmol}^{-1} \mathrm{H}_{2} \mathrm{O}_{2}$. Three independent experiments were performed using a fresh semen sample for each experiment. Treatment with $\mathrm{NaOH}$ was carried out to unwind the spermatozoal DNA for 1 min before electrophoresis. Data are expressed as mean \pm SD. Bars not sharing the common letters (a-d) differ significantly $(P<0.05)$. $\mathrm{H}_{2} \mathrm{O}_{2}$, hydrogen peroxide; MMS, methyl methanesulfonate.

We demonstrated that short-term ( $1 \mathrm{~min})$ treatment with alkali is adequate to detect accurately the DNA damage induced in human spermatozoa by MMS and $\mathrm{H}_{2} \mathrm{O}_{2}$ (Figure 3). As previously reported by Hughes et al., ${ }^{11}$ background DNA damage in human spermatozoa is higher $(11.2 \%$, Figure $5 \mathrm{a} ; 19.1 \%$, Figure $5 \mathrm{~b})$ than that in mouse spermatozoa $(3.53 \%$, Figure $1 ; 4.40 \%$, Figure $3 ; 10.5 \%$, Figure 4$)$, being similar to the baseline in somatic cells.

According to the present $\mathrm{A} / \mathrm{N}$ protocol, alkali treatment carried out for $1 \mathrm{~min}$ is sufficient for unwinding the DNA in mouse, and probably, human spermatozoa.

1 Baumgartner A, Cemeli E, Anderson D. The comet assay in male reproductive toxicology. Cell Biol Toxicol 2009; 25: 81-98.

2 Angelis KJ, Dusinska M, Collins AR. Single cell gel electrophoresis: detection of DNA damage at different levels of sensitivity. Electrophoresis 1999; 20: 2133-8.

3 Koppen G, Angelis KJ. Repair of X-ray induced DNA damage measured by the comet assay in roots of Vicia faba. Environ Mol Mutagen 1998; 32: 281-5.
4 Menke M, Chen IP, Angelis KJ, Schubert I. DNA damage and repair in Arabidopsis thaliana as measured by the comet assay after treatment with different classes of genotoxins. Mutat Res 2001; 493: 87-93.

5 Codrington AM, Hales BF, Robaire B. Spermiogenic germ cell phase-specific DNA damage following cyclophosphamide exposure. J Androl 2004; 25: 354-62.

6 Kawase Y, Hani T, Kamada N, Jishage K, Suzuki H. Effect of pressure at primary drying of freeze-drying mouse sperm reproduction ability and preservation potential. Reproduction 2007; 133: 841-6.

7 Kaneko T, Kimura S, Nakagata N. Importance of primary culture conditions for the development of rat ICSI embryos and long-term preservation of freeze-dried sperm. Cryobiology 2009, 58: 293-7.

8 Toyoda Y, Yokoyama M, Hosi T. Studies on the fertilization of mouse eggs in vitro: I. In vitro fertilization of eggs by fresh epididymal sperm. Jpn J Anim Reprod 1971; 16: 147-51. Japanese.

9 Kusakabe H, Kamiguchi Y, Yanagimachi R. Mouse and human spermatozoa can be freeze-dried without damaging their chromosomes. Hum Reprod 2008; 23: 233-9.

10 Yendle JE, Tinwell H, Elliott BM, Ashby J. The genetic toxicity of time: importance of DNA-unwinding time to the outcome of single-cell gel electrophoresis assays. Mutat Res 1997; 375: 125-36.

11 Hughes CM, Lewis SEM, McKelvey-Martin VJ, Thompson W. A comparison of baseline and induced DNA damage in human spermatozoa from fertile and infertile men, using a modified comet assay. Mol Hum Reprod 1996; 2: $613-9$ 